5. Професійна музична культура Закарпаття / упоряд., підготовка текстів, передм., прим. Мокану Л.М. Ужгород: Карпати, 2005. Вип.1. 420 с.

6. Росул Т. Музичне життя Закарпаття 20-30-х років ХХ століття. Ужгород: ПоліПрінт. 2002. 207 с.

7. Росул Т. Розвиток музичної освіти на Закарпатті у 20-30-ті рр. XX століття. Наукові записки Тернопільського державного педагогічного ун-ту ім. В.Гнатюка. Серія: Мистецтвознавство. №1 (8). Тернопіль, 2002. С. 55-59.

8. Сайт Ужгородського інститут культури і мистецтв. URL: Режим доступу: https://instituteculture.uz.ua (дата звернення: вересень 2019)

\title{
References
}

1. Ghrin, O.O. (2004). Professional musical art of Transcarpathia in the 19th - the first half of the 20th century: historical aspect. Uzhghorod: Ghosprozrakhunkovyj redakcijno-vydavnychyj viddil upravlinnja u spravakh presy ta informaciji. [in Ukrainain].

2. Danko, M. (2010). State music education in Transcarpathia and its achievements in the last half-century. Profesijna muzychna kuljtury Zakarpattja: etapy stanovlennja. Uzhghorod,. Vyp. 2. S.21-26 [in Ukrainain].

3. History of Uzhgorod Institute of Culture and Arts. Available at: https://institute-culture.uz.ua/prokoledzh/istoriia (accessed September 2019) [in Ukrainain].

4. Mykulanynec, L. M. (2009). Ethnocultural development of professional music culture in Transcarpathia in the second half of the twentieth century. Mystectvoznavchi zapysky : zb. nauk. pracj. Kyjiv: Milenium. Vyp. 15. S. 184-188 [in Ukrainain].

5. Professional musical culture of Transcarpathia, arrangement, preparation of texts, preface, notes Mokanu (2005). L.M. Uzhghorod: Karpaty,. Vyp.1. 420 s. [in Ukrainain].

6. Rosul, T. (2002). [The musical life of Transcarpathia in the 20-30's of the XX century]. Uzhghorod: PoliPrint. [in Ukrainain].

7. Rosul T. (2002). The development of music education in Transcarpathia in the 20-30's of the XX century. Naukovi zapysky Ternopiljsjkogho derzhavnogho pedaghoghichnogho un-tu im. V.Ghnatjuka. Serija: Mystectvoznavstvo. \#1 (8). Ternopilj,. S. 55-59. [in Ukrainain].

8. Site of Uzhgorod Institute of Culture and Arts. Available at: https://institute-culture.uz.ua (accessed September 2019) [in Ukrainain].

Стаття надійшла до редакиії 04.09.2019

Прийнято до публікаиії 10.10.2019

УДК. 781.086.1:78.071.1(510)Го

\author{
Чень Юньцзя, \\ аспірантка Національної музичної академії \\ України імені П. І. Чайковського \\ chengyunjia@hotmail.com \\ ORCID 0000-0002-0362-7912
}

\section{УВЕРТЮРА «РУХ ВІТРУ» ГО ВЕНЬЦЗІНА ЯК ЗРАЗОК ІННОВАЦІЙНОГО ПІДХОДУ ДО КИТАЙСЬКОЇ ПРОГРАМНОЇ УВЕРТЮРИ}

\begin{abstract}
Мета роботи. Стаття має на меті виведення системних рис симфонізму, як методу художнього мислення та національних особливостей китайської симфонічної музики для європейського оркестру. Методологія дослідження полягає у використанні цілісного, системного, порівняльного та історичного методів музикознавчого аналізу. Наукова новизна роботи полягає в тому, що автор вперше впроваджує до вітчизняного наукового обігу твір жанру китайської програмної симфонічної увертюри та робить спробу висвітлити особливості музичного стилю Го Веньцзіна. Висновки. Увертюра «Рух вітру» Го Веньцзіна - це яскравий зразок жанру програмної симфонічної увертюри сучасної китайської композиторської школи періоду другої половини 1990-х років. Риси програмного симфонізму виявляються у програмній назві, принципі концертності, тематичній розробці матеріалу, прийомі переінтонування, лейтмотивній системі (зокрема, лейтритмі «руху вітру», лейтінтонаціі), тематичній репризності у розділах сонатного allegro. Також особливого значення набувають стильові алюзії 3 творчістю Дж. Вільямса, Г. Ф. Генделя, Л. Бетховена, П. І. Чайковського, М. Равеля, К. Орфа, М. Глінки, М. А. Римського-Корсакова як уособлення діалогу культур: європейської із азіатською (китайською).

Ключові слова: китайський фольклор; джингоїзм; програмність; принцип концертності; лейтритм руху вітру; репризність.
\end{abstract}

(C) Чень Юньцзя, 2019 
Чень Юньцзя, аспирантка Национальной музыкальной академии Украины имени П. И. Чайковского

Увертюра «Движение ветра» Го Венызина как образец инновационного подхода к китайской программной увертюре

Цель работы. Целью статьи является выведение системных черт симфонизма, как метода художественного мышления и национальных особенностей китайской симфонической музыки для европейского оркестра. Методология исследования заключается в использовании целостного, системного, сравнительного и исторического методов музыковедческого анализа. Научная новизна работы заключается в том, что автор впервые внедряет в отечественный научный оборот произведение жанра китайской программной симфонической увертюры и пытается осветить особенности музыкального стиля Го Веньцзина. Выводы. Увертюра «Движение ветра» Го Веньцзина - яркий образец жанра программной симфонической увертюры современной китайской композиторской школы периода второй половины 1990-х годов. Черты программного симфонизма проявляются в программном названии, принципе концертности, тематической разработке материала, приеме переинтонирования, лейтмотивной системе (в частности, лейтритме «движения ветра», лейтинтонации), тематической репризности в разделах сонатного allegro. Также особое значение приобретают стилевые аллюзии с творчеством Дж. Вильямса, Г. Ф. Генделя, Л. Бетховена, П. И. Чайковского, М. Равеля, К. Орфа, М. Глинки, Н. А. Римского-Корсакова как отображение диалога культур: европейской с азиатской (китайской).

Ключевые слова: китайский фольклор; джингоизм; программность; принцип концертности; лейтритм движения ветра; репризность.

Cheng Yunjia, postgraduate of the National Music Academy of Ukraine by P. I. Tchaikovsky

Overture "Riding on the Wind" of Guo Wenjing as an example of innovative approach to Chinese programmatic overture

The purpose of the article. The article aims to derive systematic features of symphonism as a method of artistic thinking and the national peculiarities of Chinese symphonic music for a European orchestra. The methodology of the research lies in using holistic, systematic, comparative, and historical methods of musicological analysis. The scientific novelty of the work is that the author first introduces the work in the genre of the Chinese programmatic symphonic overture to the Ukrainian scientific conversation and attempts to highlight the musical style features of Guo Wenjing. Conclusions. The Overture of the Wind Movement by Guo Wenjin is a striking example of the genre of program symphonic overture of the modern Chinese composing school of the second half of the 1990s. The features of program symphony are expressed in the program title (the symbolism of the image of the wind, which in Chinese mythology is associated with the God of the Wind Fei Li), the principles of thematic development - motive development; figurative, textural, timbral contrast of sections, dialogue between orchestra groups as a sign of concert principles, re-intonation (intonational rethinking of heroic marching and contemplative pentatonic variants of the theme, combining in a new tutti sound in code), or having unifying ones the leitrhythm of the "wind movement," the leitintonation (a melodic line built on the Tertiary chants) and thematic reprise in sections of sonata-allegro. Also of particular importance are style allusions with the works of J. Williams, GF Handel, L. Beethoven, PI Tchaikovsky, M. Ravel, K. Orf, M. Glinka, MA Rimsky-Korsakov as a personification of dialogue. Cultures: European and Asian (whose features are manifested in the appeal to the pentatonic, the timbre of the Chinese folk dagger percussion instrument, the contrast of instruments in orchestration: the predominance of timbre strings, harps, piccolo flute, oboe, etc., typical game techniques).

Key words: Chinese folklore; jingoism; programming; the performability principle; the leitrhythm of Riding on the Wind; reprising.

Актуальність теми дослідження. Музичне мистецтво в Китайській народній республіці відіграє провідну роль та є одним зі стовпів розвитку країни. Це не виглядає дивним, оскільки музика в житті мешканців відігравала важливу роль, починаючи зі стародавньої епохи. У межах пропонованої статті простежимо характер прояву симфонізму, як важливого чинника мислення, на прикладі жанру «програмна симфонічна увертюра» 3 точки зору інноваційного підходу сучасного китайського композитора Го Веньцзіна - зародження самостійної моделі на засадах європейських норм і авторського переосмислення національних елементів.

Аналіз досліджень і публікацій. Нині у китайському музикознавці спостерігаємо активний інтерес до жанрового спектру китайської академічної музики. Питанню виникнення і розвитку китайської симфонічної музики присвячено чимало робіт, але в них здебільшого немає поглибленого і спеціального вивчення цієї теми (роботи Су Юйчен [4], Ло Шиі [2], Лі Ланьцина [1], Лян Маочуня [3]). Проблема «програмна симфонічна увертюра в творчості китайських композиторів» ще не отримала належного наукового осмислення, чим пояснюється актуальність пропонованої теми.

Мета дослідження - виведення, крізь аналіз композиційно-драматургічної побудови творів, системних рис симфонізму, як методу художнього мислення та, зокрема, національних особливостей китайської симфонічної музики для європейського оркестру.

Виклад основного матеріалу. Го Веньцзін (англ. Guo Wenjing) - сучасний китайський композитор i педагог. Народився 1 лютого 1956 року в м. Чунцін (Chongqing), провінції Сичуань, південного заходу Китаю. Закінчив Центральну консерваторію (м. Пекін) по класу композиції Лі Йінхая і Су Ся (1978), 3 
1990 року - професор, віце-директор кафедри композиції Пекінської консерваторії.На відміну від багатьох китайських композиторів, які переїхали закордон і там отримали музичну освіту, навчався і працював у Пекіні, за виключенням короткого проміжку часу - від’їду на два місяці до Нью-Йорку (1996) для викладання лекцій і майстер-класів із композиції у американських університетах. Його музика звучала на музичних фестивалях і фестивалях мистецтв у Китаї, Ірландії, Великій Британії, Нідерландах, Німеччині, Франції, Австралії, США та ін., твори публікуються у нотному видавництві Casa Ricordi. Творам 1980х років притаманні впливи Б. Бартока і К. Пендерецького («Підвішені стародавні труни на скелях у провінції Сичуань» (“Suspended Ancient Coffins on the Cliffs in Sichuan” (1983) і Д. Шостаковича (Концерт для скрипки (1986-1987) і симфонічна поема "Shu Dao Nan" для тенора соло, хору і оркестру за Лі Байя, тв. 15 (1987). У 1990-х роках у жанрі камерної опери композитор поєднує європейську школу із китайським фольклором: («Село вовченя» (“Wolf Cub Village”, 1994), «Щоденник божевілля» (“Kuangren riji”) i «Нічний банкет» (“Ye yan", 1998). У 2000-х роках митця захоплює експериментування в області музичного театру (зокрема, авторське переосмислення рис традиційної опери Сичуань, пекінської опери) у трилогії: "Мu Guiying" (2003), "Hua Mulan" (2004) та "Liang Hongyu" (2008), а також вплив Дж. Пуччіні у відбитті на китайському грунті в балеті «Павільйон Півонії» (“Peony Pavilion”) (2008) [6]. У 2010-х роках композитор у сучасній китайській опері об'єднує різноманітні вокальні елементи з китайським буддизмом, тибетським буддизмом і хорові твори, створені під час європейського ренесансу («Рикша-хлопчик» (“The Rickshaw Boy”) (2015), «Відлуння неба і землі» (“Echo of Heaven and Earth”) для капели і ударних). Також Го Веньцзін відомий і музикою до кінофільмів, музикою для церемонії відкриття Літніх Олімпійських ігор у Пекіні 2008 року.

«Рух вітру» ("Riding on the Wind") для симфонічного i великого військового оркестрів був створений Го Веньцінем 4 липня 1997 року на честь триденного святкування передачі адміністративного району Гонконгу зі складу Великої Британії Китаю та вбирає в себе естетику джингоїзму. Прем'єра відбулася в Гонконзькому Колізеї, проведеної Ю Лонгом. Пізніше твір виконувався Китайським філармонічним оркестром (16 грудня 2000 року на концерті-відкритті Китайського філармонійного оркестру), Симфонічним оркестром Віденського Національного оперного театру (2003), Шанхайським симфонічним оркестром (2012), а 1 липня 2018 року на 21 -річницю цієї знаменної події- Філармонічним оркестром Гонконгу (HK Phil) в залі Гонконгського культурного центру.

Кінематографічна програмність твору - подорож Гонконгу до возз'єднання із Китаєм, підкріплена досвідом роботи Го Веньцзіня у жанрі кіномузики, стилістично змікстованої з елементами традиційної китайської музики. Відзначимо також наявність стильової алюзії у «Русі вітру» до симфонічної сюїти 3 музики до кінофільму «Ковбої» (1972) Дж. Вільямса насамперед тим, що обидві композиції поєднуються структурним принципом побудови музичної форми: чергуванням контрастних тем «героїчної відважності і мужності» та «чуттєвої лірики» 3 поступовим переінтонуванням та їхнім тематичним спорідненням (характерна риса симфонізму П. І. Чайковського). Кінцевий результат драматургічного розвитку - перемога героїчного образу, що стає художньої алегорією повернення земель Гонконгу до складу Китаю. У випадку Дж. Вільямса героїчний образ - це ковбої, а у Го Веньцзіна - китайський народ, уособленням якого є тема свободи Гонконгу від британської експансії. Можливо, саме така стильова алюзія до образу ковбоїв, як носіїв англомовної культури (колоністів Англії на теренах Північної Америки) і відображує багаторічне джингоїстичне домінування європейської (англійської) культури над східно-азіатською (китайською) на політичному, економічному і національному рівнях.

Стильова алюзія до сюїти Дж. Вільямса ще підкріплена і національними елементами - зверненням до тембрального звучання губної гармоніки і банджо (як невід'ємного образу ранчо), специфічних ударних інструментів (хлист, як звукозображальний засіб - «підбадьорювання» коней вершником), електронних інструментів у епізодах. Ознакою симфонізації форми сюїти є лейтритм, що відображує рух колеса. Однак програмний зміст увертюри «Руху вітру» диктує свої особливості. Спорідненим із музикою Дж. Вільямса формоутворюючими елементами твору стають лейтритм «руху вітру», принцип образної, фактурної, тембральної варіантивності розділів і репризність, а також розширений склад дерев'яно-, мідно-духової і ударної групи оркестру.

Окрім стильової алюзії до музики Дж. Вільямса відчутна спорідненість із «Музикою на воді» Г. Ф. Генделя, з ії святковістю, урочистістю звучання на відкритому повітрі i, відповідно, збільшеному складу оркестру, що в принципі, відповідає початковій задумці китайського автора - всенародного святкування приєднання Гонконга до Китаю.

Якщо, умовно кажучи, урочисті епізоди відносимо до образу Великої Британії і європейської музичної традиції загалом (через стильову алюзію до творчості Дж. Вільямса, Г. Ф. Генделя, П. І. Чайковського), то ліричні епізоди є уособленням філософії споглядання, душевної чуттєвості і навіть 
жіночності, тобто китайської культури, через звернення до пентатоніки, переважання тембрів струнних, арфи, флейти piccolo, гобоя.

Також композиційним об'єднувальним чинником, окрім лейтритму руху вітру і тематичної репризності у розділах сонатного allegro (першої частини сонатно-симфонічного циклу), вміщеного у тричастинну форму з елементами розробки і епічною кодою (до речі, близької за типом епічного симфонізму О. Бородіна), стає лейтінтонація (терцієві поспівки), що пронизує усі образні сфери контрастних розділів. Кода інтонаційно переосмислює героїчно-маршовий і споглядальний пентатонічний варіанти, об'єднуючи у новому tutti' йному звучанні (ніби символізуючи братське возз'єднання народів Європи і Азії). Останній факт, алюзійно відсилає до фіналу Дев'ятої симфонії Л. Бетховена і тексту Ф. Шиллера «Ода радості».

Символічна програмна назва увертюри. Го Веньцзін звертається до символіки образу вітру, якого в китайській міфології пов'язують із Богом вітру Фей Лянь (Fēi Lián). «B його імені ієрогліф 飛 (Фей) означає “літати”, а ієрогліф 䈴 (Лянь) - “безкорисливий”. Магічні сили пов'язують Фей Ляня як з морем, так і 3 небом» [5].

Партитура «Руху вітру» включає в себе класичний потрійний склад симфонічного оркестру без англійського рожка і контрафагота та за участю китайського народного ударного інструменту дагу, а також великий змішаний духовий (військовий) оркестр без литавр. Форма сонатного allegro увертюри (за принципами мотивного розвитку) тематично вирішена у складній тричастинній формі 3 елементами розробки і епічною кодою. Перший розділ тричастинної форми- вступ (І розділ) $\boldsymbol{d}=144$ ( $\delta=288)$, експозиційний розділ із елементами розробки та динамічною репризою Agitato $\mathcal{J}=144(\boldsymbol{\delta}=288)$ т. 48 , середній розділ (епізод на новому матеріалі) - Andant extensively - Largamente (т. 171), реприза тричастинної форми з епічною кодою Agitato $\delta=144(\delta=288)$, в якій з т. 271 (епічна кода) $d=152(\boldsymbol{d}=144)$ розширюється оркестрова палітра військовим оркестром (Millitary Band).

Експозиційний розділ «Руху вітру» $\boldsymbol{J}=144(\boldsymbol{\delta}=\mathbf{2 8 8})$ можна співвідносити за принципами тонального, тематичного розгортання, оркеструванням і музичною драматургією 3 фіналом Дев'ятої симфонії Л. Бетховена. Твір відкривається вступом, тематизм якого поступово формується у партіях фаготу, контрабасу та ударних (дагу, литавр, тенорового і великого барабанів, тарілок (Hi-hat cymbal) (тт. 1-10). Потім додаються партії мідних духових - труби, тромбонів, туби, розширюється група ударних до повного складу, а з т. 10 - валторни і струнні. Ознаками формування слугують: тонічний (партія контрабасу, труб і валторн, віолончелей) і домінантовий (партія фаготів, арфи, скрипок і альтів) органні пункти, поступові імітаційного типу вступи партій (дагу, теноровий і великий барабани, тарілки), які повторюють i доповнюють ритмічний малюнок теми, що веде партія литавр. Мелодія будується на квінтовому висхідному і низхідному ходах, непомітно зачіпаючи 4 щабель $C-d u r$.

Хвиля імітаційного розвитку теми литавр виливається у переінтонований матеріал основного розділу увертюри (т. 23), що подається у концертуючому діалозі дерев'яних, мідних духових із струнною групою. Переінтонування основної теми у партіях духових виявляється у збереженні низхідного i висхідного векторів мелодичного руху, але у зміні ритму, розміру (з перемінного розміру 7/8-5/8-7/8 на 5/84/8-3/8-4/8 і далі потактові зміни), оркестровому викладенні, акцентуванням на $f f$ окремих долей такту ударними інструментами.

Переінтонована тема вступу у струнних зберігає більшу спорідненість із першими проведенням лейттеми завдяки органному пункту VII низької та I щабля та квінтовій поспівці фаготів, віолончелей $\mathrm{i}$ контрабасів. До речі, тема, що тепер проходить у скрипок і альтів, близька до фольклорних прадавніх пісень, побудованих на вузькому амбітусі (двох-трьох звуках - т. 30-35).

Автор розвиває цю тему модуляціями-співставленнями - з C-dur в Des-dur, з Des-dur в B-dur, з B-dur в $H$-dur, з $H$-dur в $C$-dur (т. 36-43), підкріплюючи нову тональність проведенням теми вступу у $C$-dur у партіях дерев'яних і мідних духових інструментів. Урочистість оркестровому звучанню додають скандування основного тону «с» і тонічної квінти у партії труб, тромбонів і туби, а також висхідні октавні glissando арфи $\left(G-g^{3}\right)$ та Т6 4 -педаль струнних.

Динамізована реприза (т. 48-170) акумулює в собі тематизм попередніх розділів і принципи його розробки. Завдяки прийому ритмічного залігування, зміні розмірів (подекуди потактових), пентаточній будові мелодичної лінії (партія струнних) і квінтових поспівок із органною педаллю та широким висхідним ходам тонічними тризвуками (партія арфи) у оркестровому супроводі створюється ефект просторовості, епічності звучання з елементами народного фольклору Сходу.

Викладення основної теми, знову ж таки у переінтонованному вигляді, відбувається у партії струнних (перше проведення: 22 такти, 103 такти - розвиток). Її розвиток будується на октавному 
перенесенні угору, поділі на мотиви (від 4 тактів і більше) та мотивному проведенні теми (функція діалогу) як у партії струнних, так і у партіях валторни, труб, тромбонів і туби, флейти, гобою і кларнета. Як темисупутники основну тему супроводжують попередні іії варіанти: тема вступу у литавр тепер виконується разом із партією фаготу, а тематизм розділу діалогу дерев'яних і мідних духових у акордовій фактурі за принципом концертування, втілився у окремі терцієві поспівки із дещо видозміненою ритмікою (партія флейти, уся група мідних, партії труби, тромбона і туби). Композитор додає до музичної тканини супроводу основної теми у струнних їі попередній варіант (тт. 30-35), але у мелодичному оберненні- замість низхідного руху, вузького амбітусу і розміру $7 / 8$, тепер - висхідний рух із елементами остинатного розвитку (вичленовування чотиритактового мотиву, котрий змінює свою звуковисотність), перемінністю розміру (7/8-5/8-4/8) та переоркеструванню для партій валторни (тт. 68-85), труби і флейти.

Середній розділ (епізод на новому матеріалі- т. 171-210), написаний у простій двочастинній репризній формі (перший період 28 тактів: перше речення 12 тактів, друге - 17 тактів; другий період 12 тактів). Відсилає до правічної історії Китаю, з його філософською споглядальністю, вибором тембрів гобою, флейти та інших духових інструментів (для зображання образу природи). Фольклорність звучання доповнюють і ладове забарвлення пентатоніки, і мотивна побудова мелодичної лінії квадратної будови: двоі чотиритактами у розмірі 4/4 (до речі, перший випадок звернення до «квадратних» розмірів у творі). Навіть відмітимо віддалену алюзію до епічних образів Баяна $з$ опери «Руслан і Людмила» М. Глінки та гусляра Садка 3 однойменної опери М. А. Римського-Корсакова завдяки чергуванню унісонного 3 оркестровим звучанням (як заспів гусляра і хоровий приспів) з поступовим розвитком динамічної драматургії розділу. Певна паралель із цими операми відображається і в музичному плані- натуральний мінор (сі мінор) i пентатоніка, але без фрігійського ладу і супроводу арфи (як образ гуслей) i фортепіано. Національний китайський колорит підкреслюють ритмічні подрібнення на останніх долях такту (рух шістнадцятими, тріолями, пунктирний ритм, введення ударної групи: великого барабану, тарілок і дагу на сильній і відносно сильних долях такту з характерними прийомами гри - підкресленими форшлагами, акцентами, тремоло) при статечному звучанні, багаті на градацію динамічні відтінки «розмовних» фраз (партія II труби $-p p<p$ mp у тт. 183-184; партія гобоя і фаготу - $m p f p$ mp $f f$ у тт. 195-199 тощо).

Реприза (з 211 такту) - проста двочастинна форма 310 тактовим вступом, кількісно співпадає із першим розділом увертюри (на відміну від складної тричастинної форми І розділу). Але загалом, функціонально являє собою складну тричастинну форму, адже за тематизмом і репризним проведенням усіх інваріантів основної лейттеми композиції в поліфонічній багатошаровості музичної тканини партитури твір вимагав логічного завершення епічною кодою (з т. 271 =152 (d = 144) за участю основного симфонічного і військового оркестрів.

У розділі калейдоскопічно, немов вітер, змінюють один одного варіанти лейттеми: із репризи першого розділу складної тричастинної форми Agitato $\boldsymbol{d}=144(\boldsymbol{\delta}=288)$ (т. 48) у партіях валторн і I скрипки (тт. 221-240) та, як відповідь на неї, переінтонована тема вступу у викладенні терціями у партіях труб і тромбонів замість експозиційних литавр, а потім струнних. У другій частині двочастинної форми репризи як тема-втора звучить переінтонована лейттема 3 тої ж репризи першого розділу експозиції, але у переоркеструванні - у партії валторн, тромбонів і туб, литавр, флейт і труб, партіях флейт, труб, Military Band, I і II скрипок, гобоїв.

Iз 310 такту композитор звертається до принципів концертування оркестру: діалогу між усім оркестром і партіями струнних, i басовими партіями усіх груп оркестру. В оркестрі звучить тема першого розділу експозиції увертюри у розширеному складі (Millitary Band, труби, ударні замість тільки духової групи), а у струнних - домінантовий органний пункт до мажору (із вступу) і тема вступу литавр у фагота, туби, литавр, малого і великого барабанів, тарілок, дагу, Millitary Band, віолончелей і контрабасу як підсумовуюче проведення лейтритму, що підхоплюється усім оркестром у останніх тритактах.

Ознаками урочистої гімнічної репризи й коди слугують задіяність усього складу оркестрів (особливо ударної групи), парність груп за функціями (цілісне проведення мелодичної лінії або окремих мелодичних фраз, гармонічного супроводу і ритмічного обрису), акордова фактура, принципи концертності, що виявляється в діалозі груп оркестру (партія тромбонів і труб з литаврами), віртуозність виконання - у насиченості кожної партії складними технічними прийомами виконання (зокрема, трелі в третій октаві та квінтольні висхідні пасажі дерев'яних духових, динамічні градації у групі мідних духових (sff $p<f f)$ та постійні зміни динаміки в межах підвищено голосного звучання оркестру $(f-f f-f f f-f f-f-f f-f f f)$, glissando арфи, як тематичні пасажі або хвилі-зв'язки, насиченість партитури акцентами окремих нот, трелями, складними мордентами, ферматами (навіть у ударних!), потактова перемінність розмірів, поліритмія у окремих фразах; часова розтягненість викладення матеріалу (перевага таких ритмічних довжин, як: цілої та половинної, постійного залігування більш дрібних довжин - чвертей із крапкою, чвертей), тонічна і домінантова педаль 
органних пунктів (лейтприйом) стає головним чинником репризності. Монотематизм, лейтритмізація, насиченість прийомами, розширений склад оркестру і розділення на під-партії у групах інструментів відсилає слухача до вершини західноєвропейського зразка віртуозного симфонізму «Болеро» М. Равеля.

Висновки. Увертюра «Рух вітру» Го Веньцзіна - це яскравий зразок жанру програмної симфонічної увертюри сучасної китайської композиторської школи періоду другої половини 1990-х років. Риси програмного симфонізму виявляються у програмній назві (символіку образу вітру, яку в китайській міфології пов'язують із Богом вітру Фей Ляй), принципах тематичної розробки - мотивного розвитку; образного, фактурного, тембрального контрасту розділів, діалогу між групами оркестру як ознакою принципів концертності, переінтонування (інтонаційне переосмислення героїчно-маршового i споглядального пентатонічного варіантів теми, об'єднуючи у новому tutti'йному звучанні в коді), у наявності об'єднувальних чинників - лейтритму «руху вітру», лейтінтонація (мелодична лінія, побудована на терцієвих поспівках) та тематичної репризності у розділах сонатного allegro. Також особливого значення набувають стильові алюзії з творчістю Дж. Вільямса, Г. Ф. Генделя, Л. Бетховена, П. І. Чайковського, М. Равеля, К. Орфа, М. Глінки, М. А. Римського-Корсакова як уособлення діалогу культур: європейської із азіатською (риси якої виявляються у зверненні до пентатоніки, тембру китайського народного ударного інструменту дагу, контрасту інструментів у оркестровці: переважанні тембрів струнних, арфи, флейти пікколо, гобоя тощо, характерних прийомах гри).

\section{Jimepamypa}

1. Ли Ланьцин. Чжунго цзаоци цзяосян иньюэ [李岗清.中国早期的交响音乐]. Ранний этап развития китайской симфонической музыки // Размышления о современной китайской музыке: сб.ст./ Сост.: Ли Ланьцин. Пекин : Гаодэн цзяою чубаньшэ, 2008. - С. 23-32.

2. Ло Шии. Симфонические жанры в контексте китайской музыкальной культуры : автореф. дис. ... на соиск. науч. степ. канд. искусствоведения : спец. 17.00.02 / Ло Шии. - Москва : Российская Академия музыки имени Гнесиных, 2003. $-21 \mathrm{c}$.

3. Лян Маочунь, Сян Сяоган, Ли Янь. Чжунго иньюэ луньбянь [梁茂春, 项䈜刚, 李岩.中国音乐论辩]. Дискуссии о китайской музыке / Лян Маочунь, Сян Сяоган, Ли Янь. - Наньчан : Байхуачжоу ищу чубаньшэ, 2007. $-438 \mathrm{c}$.

4. Су Юйчен. Композиційно-драматургічні особливості китайських програмних концертів для соліста з оркестром традиційних інструментів : Дис. ... на здоб. наук. ст. канд. мистецтвознавства: спец. 17.00.03 / Су Юйчен. Київ : НМАУ імені П. І. Чайковського, 2017. - 188 с.

5. Фэй Лянь. URL:

https://ru.wikipedia.org/wiki/\%D0\%A4\%D1\%8D\%D0\%B9_\%D0\%9B\%D1\%8F\%D0\%BD\%D1\%8C (дата звернення: 5.07.2019).

6. Guo Wenjing. Compositeur chinois né le ler février 1956 à Chongqing (Sichuan)/Guo Wenjing. URL: http://brahms.ircam.fr/wenjing-guo (дата звернення: 3.07.2019).

\section{References}

1. Lǐ Lánqīng. (2008). Zhongguo Zaoqi Jiaoxiang Yingue [李岗清.中国早期的交响音乐]. Early Chinese Symphonic Music. Thoughts on Contemporary Chinese Music. Beijing : Gaoden Jiao Chubanshe, $23-32$ [in Chinese].

2. Lo Shii. (2003). Symphonic Genres in the Context of Chinese Musical Culture. Extended abstract of candidate's thesis. Moscow : Gnesins Russian Academy of Music [in Russian].

3. Lyan Maochun, Xiang Yugang, Li Yan. Zhongguo Yinhe Lunbian [梁茂春, 项篠刚, 李岩.中国音乐论辩] (2007). Discussions on Chinese Music. Nánchāng : Baihuachzhou wǒ zhèngzài xúnzhăo Chubanshe. [in Chinese].

4. Su Yucheng. (2017). Compositional and Dramatic Features of Chinese Programmatic Concertos for Soloist and Orchestra of Traditional Instruments Extended abstract of candidate's thesis. Kyiv : Tchaikovsky NMAU [in Ukrainian].

5. Fey Lyan. Retrieved from

https://ru.wikipedia.org/wiki/\%D0\%A4\%D1\%8D\%D0\%B9_\%D0\%9B\%D1\%8F\%D0\%BD\%D1\%8C.

6. Guo Wenjing. Compositeur chinois né le 1er février 1956 à Chongqing (Sichuan). Retrieved from http://brahms.ircam.fr/wenjing-guo. 